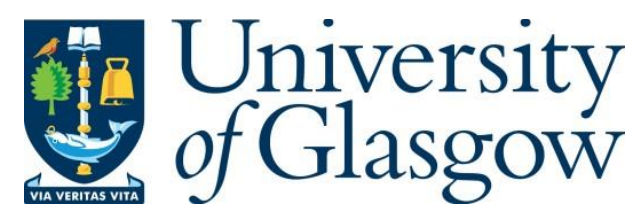

Brown, R. (2017) Scotland, Britain, Europe: parallels with Eighteenth-Century political debate. Scottish Affairs.

There may be differences between this version and the published version. You are advised to consult the publisher's version if you wish to cite from it.

http://eprints.gla.ac.uk/150381/

Deposited on: 7 November 2017

Enlighten - Research publications by members of the University of Glasgow

http://eprints.gla.ac.uk 


\title{
Scotland, Britain, Europe: Parallels with Eighteenth-Century Political Debate
}

\section{Rhona Brown}

\begin{abstract}
This article focuses on the controversial eighteenth-century Whig politician, John Wilkes (172597), his journalism and his reception in the Scottish periodical press, while considering parallels with current debates on Brexit and Scottish independence. Wilkes, seen by some at the time as a notorious rabble-rouser and a voracious Scotophobe, was nevertheless elected democratically (an unusual phenomenon at this time) to various political offices while campaigning for the freedom of the press. His outspoken attacks on the Scottish Prime Minister, Lord Bute, and associated insults to Scotland, prompted an angry response in the Scottish press and magnified the political divide between Scotland and England. If Wilkes represented 'liberty' to many English Whigs, he symbolised outspoken prejudice to many in Scotland. The article will examine some of Wilkes's own pronouncements on the Scots in his North Briton magazine, alongside responses in the contemporary Scottish periodical press. The debates that Wilkes focuses on - Scotland's socalled 'rebellious' nature and its unhelpful attachment to continental Europe - resonate with twenty-first-century political debates in illuminating ways.
\end{abstract}

\section{Keywords}

Eighteenth-century politics; Eighteenth-century Anglo-Scottish relations; John Wilkes; Scottish independence; Brexit

\section{Introduction}

Political and cultural parallels between the eighteenth and twenty-first centuries have always been there, but with each passing day following the so-called Brexit vote of 23 June 2016, they have intensified in their significance. Although its strategy is unclear at the time of writing, we know that, in response to Scotland's vote to remain in the EU, the Scottish Government will at least consider holding another referendum on Scottish independence. In a recent interview with the New Statesman, Scottish First Minister Nicola Sturgeon expressed the view that 'understandably people feel very uncertain about everything just now, partly because the past few years have been one big decision after another'. She continued, 'we have to come back when 
things are clearer and decide whether we want to do it and in what timescale' (Deerin, 2017). This 'wait and see' approach is clearly the product of an ever-changing and complex political picture.

\section{A British Brexit?}

In October 2016, three months after the Brexit vote, Prime Minister Theresa May met with the leaders of the devolved nations to discuss the UK-wide approach to negotiations with the EU. As the BBC's account of the meeting between May and the Ministers states, 'the Institute for Government warned imposing a settlement on Scotland, Wales and Northern Ireland may be legally possible but "if it proves impossible to find consensus, the result may be a serious breakdown in relations between the four governments (and nations) of the UK"' (BBC News, 2016). More than a year following the referendum, and as Brexit negotiations were underway, the Scottish Government warned of a Westminster 'power grab' after the UK leaves the EU. Mike Russell, Scotland's Brexit minister, stated that, 'We know that the UK government has its eye on more than 100 policy areas. That is a direct threat to the devolution settlement which the people of Scotland overwhelmingly voted for in 1997' (Carrell, 2017). In September 2017, Russell continued: 'The Brexit negotiations have made abundantly clear that we need a radical shift in how inter-governmental relationships are managed between the UK and the devolved nations' (BBC News, 2017). This is stark language, but it is not without precedent. It also finds reflection in a moment in eighteenth-century Anglo-Scottish relations which reveals a similar gulf between Scottish and English political opinion and strategy. One source of this gulf is the English Whig politician, John Wilkes (1725-97). 


\section{John Wilkes and Scotland}

Wilkes was first elected Member of Parliament for Middlesex in 1757. He very soon came to the attention of Scottish political commentators and journalists, and received heavy coverage a decade later in one of Scotland's most successful magazines, The Weekly Magazine, or Edinburgh Amusement, edited by a major Edinburgh publisher, Walter Ruddiman (1719-81). In that magazine, Wilkes, as seen through the lens of his Scottish contemporaries, comes into focus. Beyond political commentary, however, the Weekly Magazine also features literary remarks on Wilkes's anti-Scottish sentiment, particularly in the work of its house poet, Robert Fergusson (1750-74), who went on to be a significant influence on Scotland's national poet, Robert Burns (1759-96). Fergusson published poetry in the Weekly Magazine regularly, between 1771 and 1773. He died very prematurely, aged twenty-four, in 1774. In his second-ever appearance in the paper, the twenty-year-old Fergusson published the second of a trio of pastoral poems, entitled 'Pastoral II: Noon'. In this densely Scottish pastoral, with its 'Caledonian swains', the debating shepherds, Corydon and Timanthes, discuss Corydon's lover, Delia, and her relocation from Scotland to 'the Anglian plains'. England, for these Scottish shepherds, is a place 'Where civil discord and sedition reign'. Later in the poem, Corydon bemoans the relationship between the Scots and English when he laments that, south of the border:

Scotia's sons in odious light appear,

Tho' we for them have wav'd the hostile spear:

For them my sire, enwrapp'd in curdled gore,

Breath'd his last moments on a foreign shore (Fergusson, 1771; McDiarmid, 1954-6, II: 
Fergusson's poem begins to illuminate the mid-eighteenth-century context under consideration here. England is a place where 'civil discord and sedition' rule the day, but it is also a place where Scots are seen as 'odious', despite their having fought and died for Britain's cause. With these statements, Fergusson sheds light on the often ferocious debates surrounding Wilkes and Scotland.

\section{Wilkes's Career}

The career of John Wilkes, English politician, journalist, libertine and scholar, marked social unrest in London, resulting in the Massacre of St. George's Fields in 1768. He was imprisoned for seditious libel and obscenity, the latter thanks to his pornographic parody of Alexander Pope's Essay on Man, the Essay on Woman. He was successful politically, eventually becoming Lord Mayor of London. His major campaigns included the drive for extension of the franchise and increased freedom of the press. His radical politics attracted attention in America, and are said to have influenced its Revolution and constitution.

Although many eighteenth-century Scots may have supported Wilkes's campaign for political and journalistic liberty, Wilkes nevertheless became a target of national detestation in Scotland to the extent that his effigy was burned at rallies in Edinburgh until at least a century after his death. According to Linda Colley, 'Wilkes's outright hostility to Scotland is often marginalised as a regrettable vulgarity of no real relevance to the movement that gathered around him' (106). This rhetoric - of undesirable consequences to legitimate political debates - is familiar in wider discussions beyond Anglo-Scottish relations in 2017, as Brexit negotiations continue and Nigel Farage, former leader of the UK Independence Party, prepares to speak at a far-right rally in 
Germany on 'developments in the European Union, Brexit, direct democracy' and 'how to make the impossible possible' (Oltermann, 2017).

\section{British Opinion Divided}

Scottish anger against Wilkes is in plain sight in the Weekly Magazine and beyond, but before considering specific responses, two central questions must be posed: why was Wilkes a hero for many English people, and a villain for many Scots? How did he divide the British nation, as Brexit has done in the twenty-first century? There are a number of answers to these questions. Alongside political differences (many commentators contrast the prominence of the English Whigs at this time with Scots Toryism, thus oversimplifying a complex political situation), antiWilkes feeling in Scotland was largely fuelled by his often violently Scotophobic newspaper, The North Briton. In this publishing enterprise, Wilkes was responding to his contemporary political situation and garnering support for himself and the Whigs. More specifically, he was responding to the conduct and premiership of the most prominent and powerful contemporary Scot, John Stuart, third Earl of Bute, Tory Prime Minister for only a short time between 1762 and 1763.

In Wilkes's eyes, Bute's election to the highest office in Britain was evidence of deep-seated injustice in the British constitution that was ripe for forceful challenge from political opponents. In this time before democratic election, Bute came to power as a 'favourite' of George III, after years of intimate proximity to the royal family following a shrewd move south of the border after the Jacobite rebellions. Furthermore, he was responsible for ending the Seven Years' War by signing the Treaty of Paris, which ensured peace between Britain and France. This latter gesture, 
for Wilkes, was evidence that Bute was a 'Jacobite at heart', and that, recalling the longestablished 'Auld Alliance' between Scotland and France, Bute would prioritise Scottish interests before English ones.

\section{A United Britain?}

Wilkes's response to the Treaty of Paris demonstrates another factor in this complex AngloScottish encounter: more than half a century after the Union of 1707, prominent politicians such as Wilkes were unable to conceive of a united Britain, and still thought of the Anglo-Scottish Union as a marriage between two essentially separate - and politically different - nations. In Wilkes's time, the contemporary press and satirical print industry began, with one eye on Jacobite rebellion north of the Border, to portray Scots not only as disobedient, uncivilised and unmanageable but, at the same time, and with the other eye on Bute's prominence, as gaining too much political power in British government. Although the rhetoric is very different in twentyfirst century British commentary, constructions of Scotland as closer to Europe and, therefore, pro-EU, sit alongside increasing consideration of the political differences between English and Scottish voters and post-2014 depictions of Britain as a 'marriage' of nations which is under threat. As in Wilkes's time, commentators are currently questioning the very idea of a happily wedded Britain in a time of political division. These constructions also persist in wider debates, notably in the extensively publicised and contested Brexit 'divorce bill'.

\section{The North Briton}

In an attempt to address the divisions between the national peoples under his care, Bute ordered the creation of a new, pro-government newspaper, entitled The Briton, which was edited by 
another prominent Scot, the novelist Tobias Smollett. Incensed by this Scottish attempt to speak for the British nation, Wilkes founded a rival paper, the sarcastically titled North Briton, largely written by himself and the poet Charles Churchill, author of a notorious anti-Scottish satire of 1763, The Prophecy of Famine. Wilkes used the paper as a vehicle through which to campaign for the liberty of the press, but its major targets were Bute, his government and the people of Scotland.

The North Briton ran to forty-six issues, after which Wilkes was jailed for seditious libel in 1764 . Issue 45 - a meaningful number, referring both to the Jacobite rebellion of 1745 and the contemporary number of Scottish MPs - was his most blusteringly combative, but a description of the Scots from The North Briton, number 44, clarifies Wilkes's stance. Here, Scots are described as 'restless and turbulent', with an unhelpful but 'constant attachment to France and declared enmity to England'. Their 'repeated perfidies and rebellions... with their servile behaviour in times of need and overbearing insolence in power, have justly rendered the very name of Scot hateful to every true Englishman' (Wilkes, 1763: 1).

\section{Scottish Responses}

Perhaps predictably, Scots responded with anger in the Weekly Magazine, which in turn follows Wilkes's career closely and with much comment. The reception of Wilkes is various throughout the Weekly Magazine, and Ruddiman makes some attempts at editorial even-handedness.

Nevertheless, Wilkes emerges as an anti-Scottish villain in its pages. Here, he is challenged to duels for Scotland's honour and branded in poetry as having 'the look sincere' but 'The toad is still betwixt his teeth,/The serpent in his eye' (Weekly Magazine, 1769: 212). Another 
commentator plays down the importance of 'faction, as long as it can be restrained, by the moderations of honest men', but asserts, more profoundly, that eighteenth-century Britain, in its 'distracted and divided state' is vulnerable, for its division has had the effect of 'excit[ing] our common enemies... to stir up a new war' (Weekly Magazine, 1771: 65-9).

\section{Conclusion}

Although Wilkes's terms are at the very least uncompromising, his depictions of the Scots and their responses to him bring major twenty-first-century political debates - most notably on whether or not Scotland should be an independent country and the differences of opinion between Scotland and England on Brexit - to mind. Since the Scottish independence referendum of 2014 and the Brexit referendum of 2017, two narratives of Anglo-Scottish relations have surfaced. The first draws on a perceived change in public opinion on Scottish independence following Brexit and the associated debates on the demographic of 'Leave' and 'Remain' voters. In an article for the Independent published in October 2016, one young Scottish voter described having voted for the status quo in 2014: 'Proudly, on the day of the vote, I put a cross in the "No" box while draped in a Union Jack'. By 2016, this voter concludes that, 'Post-Brexit, and with an independent Scotland, young people can work towards building something which works much better for all of us' (Zitser, 2016). Rather than focusing on the 'heart versus head' and 'nostalgia' arguments that often dominated the debate on Scottish independence in 2014, this author highlights differences of opinion between Scottish and British voters on major policy areas, including the redistribution of wealth, the death penalty, gay rights, immigration and the rights of immigrants (See Bialik, 2014). 
At the same time, and following both referenda, narratives have emerged which attempt to invalidate Scotland's Brexit stance. On the announcement that the Scottish Government was considering a second independence referendum following the Brexit vote, May accused Sturgeon of 'playing politics with the future of our country', while the Daily Mail's headline demanded, 'Hands off our Brexit, Nicola!' (Groves and Stevens, 2017). The fact that Scotland's opinions on Brexit were so out of step with England's raises questions on Scotland's level of selfdetermination and, just as in the time of Wilkes and Bute, Scotland is asked to consider its place in the United Kingdom. In a piece gathering genuinely diverse, 'morning after' responses to the Brexit referendum result, a Glasgow Herald article takes the words of businessman Ben Travers as its headline: 'I hope we ditch [the Scots] from the UK. I hope they do get another independence vote and we can get rid of them. And the Welsh. Then we can just be England. That's what people wanted - England back' (Frith, 2016). Parallels with eighteenth-century political questions and debates abound in these post-referenda narratives. What is the role of Britain? Does Scottish and English identity come before British identity? How do governments deal with fundamental, political differences of opinion between Scotland and England? Can Brexit proceed and Britain remain intact?

We continue to deliberate all of these issues anew in the twenty-first century, with each fresh discussion of the questions of Scottish independence and the UK nations' relationship with the EU bringing new perspectives on the debate. We continue having conversations about whether or not Scotland is an 'equal partner' in Union, its desire (or otherwise) for self-determination and the ever-vexed West Lothian Question. The Brexit referendum has only brought these questions into sharper relief. Twenty-first-century Britain is not riven by the brutal Anglo-Scottish tensions 
that characterised the 1760s and were personified by, among others, the campaigns of John Wilkes. However, as 250-year-old debates surrounding Wilkes's career and Scotland's place within Britain and Europe demonstrate, many of the problems posed by Wilkes in the eighteenth century remain with us and still await their solutions.

\section{References}

BBC News (2017). Michael Russell calls for Brexit process 'shift'. 9 September. http://www.bbc.co.uk/news/uk-scotland-scotland-politics-41212307. [Accessed 22 September 2017.]

BBC News (2016). Sturgeon tells May she's 'not bluffing' over referendum. 24 October. http://www.bbc.co.uk/news/uk-politics-37747995. [Accessed 22 September 2017.]

Bialik, C. (2014). On Policy, Scotland is Far from Most of Britain, but not London. FiveThirtyEight, 16 September.

https://fivethirtyeight.com/features/on-policy-scotland-is-far-from-most-of-britain-but-notlondon/. [Accessed 22 September 2017.]

Carrell, S. (2017). Scottish ministers press Damian Green for return of powers from EU. The Guardian, 9 August. https://www.theguardian.com/uk-news/2017/aug/09/scottish-ministerspress-damian-green-for-return-of-powers-from-eu. [Accessed 22 September 2017.]

Colley, L. (1992). Britons: Forging the Nation. New Haven, CT: Yale University Press.

Deerin, C. (2017). Interview: Nicola Sturgeon's Scottish Referendum Dilemma. New Statesman, 20 September. http://www.newstatesman.com/politics/scotland/2017/09/interview-nicolasturgeons-scottish-referendum-dilemma. [Accessed 22 September 2017]

Fergusson, R (1771). Pastoral II: Noon. The Weekly Magazine, or Edinburgh Amusement, 14 February.

Frith, M. (2016). I hope we ditch the Scots from the UK. Glasgow Herald, 26 June. http://www.heraldscotland.com/news/14580557.qquot_I_hope_we_ditch_the_Scots_from_the_U $\underline{\mathrm{K}}$ And the_Welsh_Then_we_can_just_be_England That_39_s_what_people_want Eng land_back_quot_/. [Accessed 22 September 2017.]

Groves, J. and Stevens, J. (2017). Hands off our Brexit, Nicola. Daily Mail, 14 March. http://www.dailymail.co.uk/news/article-4310906/Sturgeon-demands-new-Scottish-poll-UKheads-exit.html?ito=social-facebook. [Accessed 22 September 2017.] 
McDiarmid, M.P. (1954-56) (ed.), Poems of Robert Fergusson, 2 vols. Edinburgh: Blackwood.

Oltermann, P. (2017). Nigel Farage to address far-right rally in Germany. The Guardian, 7 September.

https://www.theguardian.com/politics/2017/sep/07/nigel-farage-to-address-far-right-rally-ingermany. [Accessed 22 September 2017.]

Weekly Magazine (1769). 'On Seeing a Print of Mr Wilkes in Alderman's Robes.' 16 February.

Weekly Magazine (1771). 17 January.

Wilkes, J. (1763) The North Briton, no. 44, 2 April.

Zitser, J. (2016). I used to be against Scottish independence - but after Brexit, I think it's the only hope for young people like me in the UK. The Independent, 17 October.

http://www.independent.co.uk/voices/brexit-article-50-theresa-may-european-union-scotlandnicola-sturgeon-snp-indyref2-independence-a7365246.html. [Accessed 22 September 2017.] 